\title{
Wspomnienie w 100. rocznicę urodzin dr hab. Ireny Rudowskiej-Jakubowicz
}

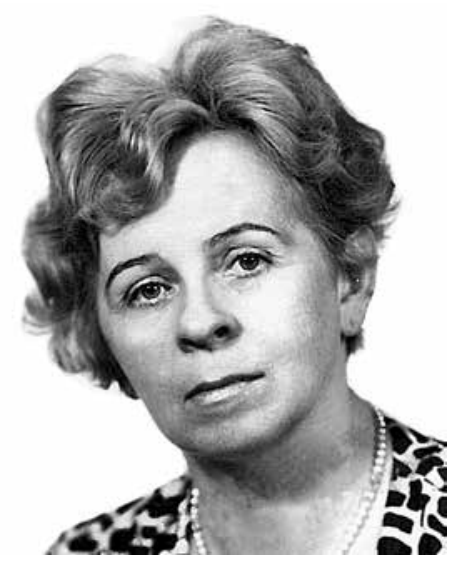

dr hab. Irena Rudowska-Jakubowicz (1918-1991)

1 września 2018 roku minęła 100. rocznica urodzin Ireny Rudowskiej-Jakubowicz, lekarza dermatologa, specjalisty kosmetyki lekarskiej. Była osobą niezwykłą - lekarzem z powołania, całe swoje życie zawodowe i naukowe poświęciła kosmetyce lekarskiej (określanej dzisiaj mianem dermatologii estetycznej). Jej wielkie osiągnięcia jako pionierki tej specjalności w Polsce zasługują na specjalną pamięć i wyróżnienie.

Urodziła się w Kijowie w rodzinie o wielkich tradycjach humanistycznych i lekarskich. Ojciec, prof. Jerzy Rutkowski, był wybitnym polskim chirurgiem, a jednocześnie wielkim humanistą, jednym $\mathrm{z}$ ostatnich lekarzy, którzy potrafili połączyć idee medycyny i humanizmu. Obok znamienitych osiągnięć w dziedzinie chirurgii pisał i tłumaczył wiersze, wykonywał artystyczne fotografie przyrody, kochał muzykę. Matka, Stanisława, z domu Dąbrowska, urodzona w Kubliczu na Podolu, zajmowała się domem i wychowaniem dzieci.

Rodzina Rutkowskich, uciekając przed rewolucją październikową z Kijowa, dotarła w 1920 roku do Warszawy.

W 1936 roku Irena Rudowska-Jakubowicz ukończyła liceum im. Juliusza Słowackiego, uzyskując świadectwo dojrzałości. W tym samym roku podjęła studia na Wydziale Lekarskim Uniwersytetu Warszawskiego i kontynuowała je do 1939 roku.

Jako młoda studentka w czasie oblężenia Warszawy we wrześniu 1939 roku brała czynny udział w ratowaniu rannych $\mathrm{w}$ charakterze sanitariuszki i pielęgniarki u boku swojego ojca, ordynatora II Oddziału
Chirurgicznego Szpitala Dzieciątka Jezus. Już wtedy dała się poznać jako odpowiedzialna i zaangażowana adeptka medycyny.

Cudem uniknęła śmierci podczas bombardowania Szpitala Dzieciątka Jezus, w wyniku którego cała rodzina znalazła się pod gruzami pawilonu II Oddziału Chirurgicznego w tragicznym dniu 25 września 1939 roku. Jej rodzice zostali ciężko ranni.

W pierwszych latach okupacji hitlerowskiej dokończyła na tajnym Uniwersytecie Warszawskim studia lekarskie i uzyskała dyplom lekarza w 1944 roku. W czasie studiów dała się poznać nie tylko jako bardzo zdolna studentka, lecz także jako organizator tajnego nauczania, przygotowując skrypty i materiały do nauki, za co została wyróżniona.

Bezpośrednio po wojnie trafiła wraz z rodziną do Łodzi, która po zburzeniu Warszawy stała się zastępczą stolicą Polski, centrum naukowym i kulturalnym.

Działalność Ireny Rudowskiej-Jakubowicz można podzielić na trzy kierunki: naukowy, kliniczny i dydaktyczny. Z tymi kierunkami wiąże się także bogata działalność wydawnicza. Działalność naukową i kliniczną rozpoczęła w latach 1945-1948, pracując jako starszy asystent w Klinice Dermatologicznej Wydziału Lekarskiego Uniwersytetu Łódzkiego kierowanej przez prof. Kapuścińskiego. Pierwszym krokiem w kierunku dydaktycznym było zorganizowanie i prowadzenie w Łodzi w latach 1945-1951 własnej, rocznej Szkoły Kosmetyki i Masażu Leczniczego, która stała się wzorem szkolenia kosmetyczek w całym kraju. Po przerwie w pracy zawodowej w latach 1948-1952 związanej z urodzeniem i wychowaniem 
dzieci podjęła ją ponownie w 1952 roku w Klinice Dermatologicznej Akademii Medycznej w Warszawie (kierownik prof. Stefania Jabłońska), rozpoczynając przygotowania do działalności w swojej ukochanej dziedzinie - kosmetyce lekarskiej. W toku pracy w Klinice Dermatologicznej uzyskała specjalizację z dermatologii i wenerologii I stopnia w 1952 roku oraz II stopnia w 1956 roku. W 1964 roku obroniła pracę doktorską pt. „Badania nad skutecznością leczenia bielactwa nabytego psoralenami i nad mechanizmem działania leku" (promotor: prof. Stefania Jabłońska).

W następnych latach zajęła się organizacją pierwszej w ośrodkach akademickich Przychodni Kosmetyki Lekarskiej, którą prowadziła przez wiele lat, wprowadzając szereg nowych metod leczenia chorób skóry. Na szczególne wyróżnienie zasługuje metoda dermabrazji, którą podsumowała w 1975 roku w publikacji wydanej nakładem własnym pt. „Obserwacje kliniczne i badania doświadczalne nad zastosowaniem dermabrazji w leczeniu niektórych chorób skóry i wad kosmetycznych". Przychodnia Kosmetyki Lekarskiej świadczyła liczne usługi dla pacjentów ambulatoryjnych i klinicznych, także w zakresie małych zabiegów chirurgicznych. W przychodni prowadzone były regularne szkolenia dla lekarzy dermatologów, kosmetyczek, a także zajęcia ze studentami IV i V roku studiów medycznych.

Obok pracy naukowej, klinicznej i dydaktycznej zajmowała się też publikowaniem. Miała dużą łatwość pisania, przyjemny styl i była bardzo pracowita. Swoje długoletnie doświadczenie przekazała lekarzom w pierwszym wydanym w Polsce podręczniku kosmetyki lekarskiej (trzy wydania, I wydanie w 1957 roku) oraz w licznych rozdziałach $\mathrm{w}$ podręcznikach i monografiach dermatologicznych. Wydała kilkanaście książek dla lekarzy, kosmetyczek i kobiet zainteresowanych metodami pielęgnacji skóry i upiększania. Wybrane tytuły to: „Kosmetyka lekarska”, „Pielęgnowanie urody (podręcznik dla kosmetyczek)” oraz pozycje popularne, np. „Książka Ewy”, ,Kosmetyka na co dzień”, ,Higiena i kosmetyka dziecka”, , Bądź zawsze młodą i piękną", ,Jak być piękną na co dzień", „Higiena pracy fryzjera”, ,Kosmetyka wczoraj i dziś”, , "Higiena i kosmetyka dzieci i młodzieży". Spis prac naukowych i dydaktycznych Ireny Rudowskiej-Jakubowicz obejmuje blisko 60 pozycji, w tym część w czasopismach niemieckich, np. „Dihydroxyaceton und seine Anwendung in der Dermatologie und Kosmetik" (Zschr Haut Geschl Krkh 1967, 42, 649).

W czasie swojej pracy w Klinice Dermatologicznej uczestniczyła w wielu zjazdach i sympozjach dotyczących postępów i osiągnięć kosmetyki lekarskiej na świecie, doskonaląc swój warsztat. W 1957 roku odbyła szkolenie w Klinice Dermatologicznej w Pradze (prof. Gawalowski), a w 1966 roku na Oddziale Kosmetyki Lekarskiej Kliniki Dermatologicznej w Monachium (doc. Schumachers-Bredler).

Pomimo tak dużej aktywności potrafiła stworzyć w Warszawie pierwszy prywatny gabinet kosmetyki lekarskiej, który zawsze traktowała jak swoje dziecko. Wkładała w jego funkcjonowanie niezwykle dużo energii i stworzyła ośrodek łączący kosmetykę lekarską na wysokim poziomie z kosmetyką upiększającą i zabiegową.

Jako ekspert w dziedzinie kształcenia kosmetyczek brała aktywny udział w wielu naradach w Ministerstwie Zdrowia poświęconych kształceniu i uprawnieniom kosmetyczek, zasiadała w Komisji do spraw Programów i Podręczników dla Szkół Zawodowych $\mathrm{w}$ tej dziedzinie.

Była członkiem Polskiego Towarzystwa Dermatologicznego oraz Lekarskiego Towarzystwa Medycyny Estetycznej w Niemczech od 1969 roku.

W ostatnich latach swojego pracowitego życia dr hab. Irena Rudowska-Jakubowicz zainteresowała się historią medycyny w zakresie kosmetyki lekarskiej. Bodźcem była inicjatywa wybitnego pediatry i historyka medycyny prof. Bolesława Górnickiego. Ten znakomity lekarz, historyk i humanista wywarł znaczący wpływ na Jej aktywność w tej dziedzinie, służąc radą i opieką.

Przychodzi refleksja - jak istotny wpływ na Jej zainteresowania, życie naukowe i zawodowe wywarli dwaj wielcy lekarze i humaniści: prof. Rutkowski ojciec i prof. Górnicki. Wynikiem tych zainteresowań były liczne publikacje na temat historycznych uwarunkowań kosmetyki oraz obszerna praca habilitacyjna "Źródła kosmetyki w piśmiennictwie polskim od XVI do końca XIX wieku" (1982 r.).

W dziedzinie historii medycyny na uwage zasługuje także opublikowany w 1990 roku w "Problemach Lekarskich” artykuł „Choroba i śmierć Barbary Radziwiłłówny” (tom XXIX, 3-4, s. 481), oparty na licznych oryginalnych źródłach historycznych.

Była dwukrotnie zamężna. Pierwszym mężem był chirurg, prof. Witold Rudowski. Miała z nim dwóch synów: Roberta - inżyniera informatyka, profesora Warszawskiego Uniwersytetu Medycznego i wieloletniego kierownika Zakładu Informatyki Medycznej i Telemedycyny, i Jerzego - inżyniera elektronika mieszkającego w Kanadzie oraz córkę, Joannę Rudowską-Okrasko - lekarza dermatologa. Drugim mężem był dermatolog, prof. Kazimierz Jakubowicz. Nie sposób nie wspomnieć o troskliwej opiece, jaką roztaczał nad Żoną w okresie Jej długoletniej choroby, a także pomocy w Jej działaniach zawodowych na rzecz rozwoju kosmetyki lekarskiej.

Była zawsze, pomimo dużego obciążenia zawodowego, osobą o niezwykle radosnym, młodzieńczym usposobieniu, bardzo towarzyska, życzliwa ludziom, 
a szczególnie pacjentom, lubiła się bawić i uśmiechać. Była uparta w najlepszym tego słowa znaczeniu. Zawsze dążyła do celu i pomimo licznych trudności cel ten osiągała.

Aktywna do ostatnich dni swojego życia - odeszła 8 lutego 1991 roku. Została pochowana na Starych Powązkach (kwatera 43). Pozostaje pamięć o Niej jako osobie niezwykłej i Jej wielkich zasługach dla polskiej kosmetyki lekarskiej.

Robert Rudowski 